\title{
Attitudes toward Medical Professionalism and Professional Medical Practices in Medical Students of Qazvin
}

\author{
Abbas Allami ${ }^{1}$, Haviv Rahban ${ }^{2}$, Navid Mohammadi ${ }^{3,4 *}$ \\ ${ }^{1}$ Department of Infectious diseases, Faculty of Medicine, Qazvin University of Medical Sciences. Qazvin, Iran. \\ 2 General physician, Qazvin University of Medical Sciences. Qazvin, Iran. \\ 3 Department of Community Medicine, Faculty of Medicine, Qazvin University of Medical Sciences, Qazvin, Iran. \\ ${ }^{4}$ Preventive Medicine and Public Health Research Center, Iran University of Medical Sciences, Tehran, Iran.
}

Article Info

Article Type:

Original Article

Article history:

Received

Accepted

Published

Keywords:

Medical Professionalism

Undergraduate medical students

Attitude

\begin{abstract}
Background and Objective: Previous literature supports consideration of professional education at undergraduate level. This research was an attempt to assess the attitudes of medical students toward medical professionalism and professional practices in Qazvin University of Medical Sciences during 2014-2015.

Materials and Methods: All medical students, in the clerkship and internship levels, enrolled in a descriptive study. Data were gathered by means of a questionnaire taking into account cultural considerations of the country.

Results: Most trainees pointed out that professionalism should be taught and learned. While half of the trainees believed that medical ethics course should be formally taught in the medical school, the others preferred its elective inclusion. The majority of the participants $(94.5 \%)$ believed that learning professionalism needs more than only a theoretical course. A longitudinal approach for teaching professionalism was the most agreed approach in comparison to time-limited course. There was a significant difference between attitude of the students and interns in terms of necessity of lifelong learning and updated knowledge, inter-professional collaboration and team-work and the importance of continuous education. Also, frequency of professional behaviors (e.g. number of weekly studied articles, use of earlier notation and participation in social services in the past few years) were statistically different based on the level of education.

Conclusion: Despite positive attitudes of medical students toward specific elements of professionalism (empathy, teamwork, and lifelong learning), they rarely take advantage of them in their behavior.
\end{abstract}

"Corresponding author: Navid Mohammadi, E-mail: nvmohammadi@qums.ac.ir

This article is referenced as follows:

Rohban H, Allami A, Mohammadi N. Attitudes toward Medical Professionalism and Professional Medical Practices in Medical Students of Qazvin . J Med Educ Dev. 2017; 10 (26) :164-174 


\section{Introduction}

Medical professionalism can be defined as the foundational understanding of ethics when applied to medicine and in recent years, its academic study is becoming very common (1). Technical knowledge, practical skills, ethics, and communication are foundations of professionalism principles. Also, medical professionalism comprises the following set of behaviors:

1- adhere to high ethical and moral standards, 2- respond to societal needs, and their behaviors (reflects a social contract with the communities served), 3demonstrate core humanistic values, including honesty and integrity, caring and compassion, altruism and empathy, respect for others, and trustworthiness, 4accountability for themselves and their colleagues, 5- demonstrate a continuing commitment to excellence, 6- exhibit a commitment to scholarship and advancing their field, 7- reflect upon their actions and decisions $(2,3)$.

Reports show that newly graduated physicians are facing problems which threaten the professional values and decrease social trust (4). Physicians' professional attitudes and ethical skills are shaped in part by their medical school trainings (5). Over the past several decades, formal curricula have been widely introduced in medical schools programs to enhance the professionalism and ethical strengths of early career physicians (6).

Understanding undergraduate medical students' perspectives about the principles of professionalism may help educators to teach undergraduate medical students about professionalism with learner-centered methods that incorporate their daily challenges as teachable moments. For a better understanding, we need to know about their attitudes and beliefs toward professional behaviors in general and also in particular about themselves. So, we designed and conducted this research to assess the medical professionalism among senior medical clerks and interns of Qazvin University of Medical Sciences.

\section{Materials and Methods}

This descriptive cross-sectional study was done at Qazvin University of Medical Sciences (QUMS) in 2014-2015. At the first step, the researchers designed a questionnaire by using articles and several previous questionnaires of similar studies by expert groups $(10,11)$, which then was adjusted according to the basics of 
professionalism, the purpose of the study, ethical and cultural issues, and the code of conducts of the University.

The questionnaire included two main parts: attitude with 24 questions, and behavior with 14 questions.

A five-point Likert scale for each question was used. The answers to the questions were rated from none to very much. Its validity was determined by Pilot test on 15 people and reliability of the instrument was assessed at Shademan's study with Cronbach' Alpha $>$ 0.85. (7). All senior medical students (year $5)$ and interns enrolled to the study with no sampling $(\mathrm{n}=145)$.

For increasing the response rate, researchers tried twice to collect the questionnaires within 1-2 weeks, although participation was not mandatory and the students were free to announce their names. Data were analyzed by T-student Test using SPSS software.

\section{Ethical considerations}

All the participants werefirstly informed about thepurposeofthestudyandassuredof anonymity prior to their participation in the study.

\section{Results}

More than 90 percent of the questionnaires were returned by the participants (131 out of 145) with a male-to-female ratio of 0.60 .
(Table 1) The mean age was $24.6 \pm 1.12$ (range 22- 28). A total of $42 \%$ of the participants were studying in the fifth (last) year of medical school and 57\% were in internship level.

The frequencies of the professional behaviors are shown in table 1 .

These behaviors [i.e. the number of weekly studied articles $(\mathrm{p}=0.025)$, use of previous notation $(\mathrm{p}=0.015)$ and participation in social services in the past few years $(p=0.047)$ ] were statistically different based on the level of education. Obviously, the interns read more articles than the medical students in a weekly basis.

Most trainees $(80 \%)$ believed that teaching of ethics and professionalism is necessary and should be taught and learned. About half of the trainees $(51.6 \%)$ expressed that ethics should be formally taught in the medical school curriculumwhile the others considered it as an elective. The majority of participants $(94.5 \%)$ believed that learning medical ethics and professionalism needs more than only a theoretical course to teach. A longitudinal approach for teaching medical ethics and professionalism was the most agreed format $(68.5 \%)$ rather than acourse in a limited time. The degree of importance of professionalism principles is shown in table 2 and reflects the 
viewpoints of participants. There was a significant difference between attitude of the clerks and interns in terms of necessity of life-long learning and having updated knowledge $\quad(p=0.044), \quad$ inter-professional collaboration and team-work $(p=0.032)$ and the importance of continuous education $(\mathrm{p}=0.030)$. In fact, undergraduate medical students had a better attitude to life-long learning and team-work strategy in comparison with interns. (Table 2)

Table 1: The frequency of professional behaviors based on medical students' answers in QUMS, 2014-2015

\begin{tabular}{|c|c|c|c|c|c|}
\hline & & \multicolumn{3}{|c|}{ Count (percent) } & \multirow[b]{2}{*}{$\mathrm{p}$} \\
\hline & & Students & Interns & Total & \\
\hline \multirow{2}{*}{ Gender } & male & $19(34.5)$ & $30(39.5)$ & $49(37.4)$ & \multirow{2}{*}{0.565} \\
\hline & female & $36(65.5)$ & $46(60.5)$ & $82(62.6)$ & \\
\hline \multirow{3}{*}{ Sending Email to patients } & frequently & $0(0.0)$ & $0(0.0)$ & $0(0.0)$ & \multirow{3}{*}{0.210} \\
\hline & rarely & $4(7.3)$ & $2(2.6)$ & $6(4.6)$ & \\
\hline & never & $51(92.7)$ & $74(97.4)$ & $125(95.4)$ & \\
\hline \multirow{3}{*}{ Using online medical education methods } & frequently & $22(40.0)$ & $35(46.1)$ & $57(43.5)$ & \multirow{3}{*}{0.125} \\
\hline & rarely & $18(32.7)$ & $31(40.8)$ & $49(37.4)$ & \\
\hline & never & $15(27.3)$ & $10(13.2)$ & $25(19.1)$ & \\
\hline \multirow{3}{*}{$\begin{array}{l}\text { Use of computerized applications for medical } \\
\text { decision making }\end{array}$} & frequently & $15(27.3)$ & $32(42.1)$ & $47(35.9)$ & \multirow{3}{*}{0.187} \\
\hline & rarely & $25(45.5)$ & $30(39.5)$ & $55(42.0)$ & \\
\hline & never & $15(27.3)$ & $14(18.4)$ & $29(22.1)$ & \\
\hline \multirow{3}{*}{ Using online journals } & frequently & $9(16.4)$ & $19(25.0)$ & $28(21.4)$ & \multirow{3}{*}{0.241} \\
\hline & rarely & $28(50.9)$ & $41(53.9)$ & $69(52.7)$ & \\
\hline & never & $18(32.7)$ & $16(21.1)$ & $34(26.0)$ & \\
\hline \multirow{3}{*}{ Reading new articles (weekly) } & None & $47(85.5)$ & $49(64.5)$ & $96(73.3)$ & \multirow{3}{*}{$0.025^{*}$} \\
\hline & $1-4$ & $8(14.5)$ & $26(34.2)$ & $34(26.0)$ & \\
\hline & $4<$ & $0(0.0)$ & $1(1.3)$ & $1(0.8)$ & \\
\hline \multirow{3}{*}{ Readiness for clinical knowledge evaluation } & yes & $9(16.4)$ & $8(10.5)$ & $17(13.0)$ & \multirow{3}{*}{0.243} \\
\hline & borderline & $26(47.3)$ & $47(61.8)$ & $73(55.7)$ & \\
\hline & no & $20(36.4)$ & $21(27.6)$ & $41(31.3)$ & \\
\hline \multirow{3}{*}{ Subscribe to charity } & No & $38(70.4)$ & $62(81.6)$ & $100(76.9)$ & \multirow{3}{*}{$0.047^{*}$} \\
\hline & yes, town/regional & $7(13.0)$ & $11(14.5)$ & $18(13.8)$ & \\
\hline & yes, country area & $9(16.7)$ & $33.9)$ & $12(9.2)$ & \\
\hline \multirow{2}{*}{ Unreported medical error } & yes & $10(18.5)$ & $25(32.9)$ & $35(26.9)$ & \multirow{2}{*}{0.069} \\
\hline & no & $44(81.5)$ & $51(67.1)$ & $95(73.1)$ & \\
\hline \multirow[b]{2}{*}{ Conflict of interest comprehension } & good & $18(72.0)$ & $27(62.8)$ & $45(66.2)$ & \multirow[b]{2}{*}{0.439} \\
\hline & $\begin{array}{c}\text { no comprehension or } \\
\text { no encounter }\end{array}$ & $7(28.0)$ & $16(37.2)$ & $23(33.8)$ & \\
\hline \multirow{2}{*}{ Presence of professionalism training } & yes & $49(98.0)$ & $55(76.4)$ & $104(85.2)$ & \multirow{2}{*}{$0.001^{*}$} \\
\hline & no & $1(2.0)$ & $17(23.6)$ & $18(14.8)$ & \\
\hline \multirow{2}{*}{ Types of courses (Elective or required courses) } & required & $29(54.7)$ & $37(49.3)$ & $66(51.6)$ & \multirow{2}{*}{0.548} \\
\hline & elective & $24(45.3)$ & $38(50.7)$ & $62(48.4)$ & \\
\hline \multirow{3}{*}{$\begin{array}{l}\text { Education type } \\
\text { required for job/role }\end{array}$} & theory & $0(0.0)$ & $7(9.3)$ & $7(5.5)$ & \\
\hline & practical & $16(30.2)$ & $20(26.7)$ & $36(28.1)$ & 0.073 \\
\hline & theory-practical & $37(69.8)$ & $48(64.0)$ & $85(66.4)$ & \\
\hline & $\begin{array}{l}\text { beginning of the } \\
\text { course }\end{array}$ & $4(7.4)$ & $11(14.5)$ & $15(11.5)$ & \\
\hline Proper time of education & throughout the course & $39(72.2)$ & $50(65.8)$ & $89(68.5)$ & 0.458 \\
\hline & $\begin{array}{c}\text { no need (except role } \\
\text { model) }\end{array}$ & $11(20.4)$ & $15(19.7)$ & $26(20.0)$ & \\
\hline
\end{tabular}


Table 2: The Importance of the principles of professionalism from the Viewpoint of medical students in

\begin{tabular}{|c|c|c|c|c|c|}
\hline \multicolumn{6}{|c|}{$Q U M S$} \\
\hline & & \multicolumn{3}{|c|}{ Count (percent) } & \multirow[t]{2}{*}{$\mathrm{p}$} \\
\hline & & Students & Intern & Total & \\
\hline \multirow{3}{*}{$\begin{array}{l}\text { Willingness to take up recertification } \\
\text { courses }\end{array}$} & Nothing or little & $13(23.6)$ & $17(22.4)$ & $30(22.9)$ & \multirow{3}{*}{0.483} \\
\hline & average & $17(30.9)$ & $31(40.8)$ & $48(36.6)$ & \\
\hline & $\begin{array}{l}\text { Much and too } \\
\text { much }\end{array}$ & $25(45.5)$ & $28(36.8)$ & $53(40.5)$ & \\
\hline \multirow{3}{*}{$\begin{array}{l}\text { Reporting their general medical } \\
\text { errors }\end{array}$} & Nothing or little & $28(50.9)$ & $28(36.8)$ & $56(42.7)$ & \multirow{3}{*}{-0.273} \\
\hline & average & $17(30.9)$ & $31(40.8)$ & $48(36.6)$ & \\
\hline & $\begin{array}{l}\text { Much and too } \\
\text { much }\end{array}$ & $10(18.2)$ & $17(22.4)$ & $27(20.6)$ & \\
\hline \multirow{3}{*}{$\begin{array}{l}\text { Reporting unqualified colleagues to } \\
\text { the responsible authorities }\end{array}$} & Nothing or little & $33(60.0)$ & $51(67.1)$ & $84(64.1)$ & \multirow{3}{*}{0.553} \\
\hline & average & $11(20.0)$ & $15(19.7)$ & $26(19.8)$ & \\
\hline & $\begin{array}{l}\text { Much and too } \\
\text { much }\end{array}$ & $11(20.0)$ & $10(13.2)$ & $21(16.0)$ & \\
\hline \multirow{3}{*}{$\begin{array}{l}\text { Not considering gender and racial } \\
\text { differences in patients' medical care }\end{array}$} & Nothing or little & $7(12.7)$ & $16(21.1)$ & $23(17.6)$ & \multirow{3}{*}{-0.121} \\
\hline & average & $6(10.9)$ & $15(19.7)$ & $21(16.0)$ & \\
\hline & $\begin{array}{l}\text { Much and too } \\
\text { much }\end{array}$ & $42(76.4)$ & $45(59.2)$ & $87(66.4)$ & \\
\hline \multirow{3}{*}{$\begin{array}{l}\text { Taking care of patients without } \\
\text { considering their financial situations } \\
\text { (to pay for the services) }\end{array}$} & Nothing or little & $5(9.1)$ & $15(19.7)$ & $20(15.3)$ & \multirow{3}{*}{-0.137} \\
\hline & average & $11(20.0)$ & $19(25.0)$ & $30(22.9)$ & \\
\hline & $\begin{array}{l}\text { Much and too } \\
\text { much }\end{array}$ & $39(70.9)$ & $42(55.3)$ & $81(61.8)$ & \\
\hline \multirow{3}{*}{$\begin{array}{l}\text { Lifelong learning and having } \\
\text { updated knowledge }\end{array}$} & Nothing or little & $1(1.8)$ & $8(10.7)$ & $9(6.9)$ & \multirow{3}{*}{0.044} \\
\hline & average & $18(32.7)$ & $14(18.7)$ & $32(24.6)$ & \\
\hline & $\begin{array}{l}\text { Much and too } \\
\text { much }\end{array}$ & $36(65.5)$ & $53(70.7)$ & $89(68.5)$ & \\
\hline \multirow{3}{*}{$\begin{array}{l}\text { Knowing and applying evidence- } \\
\text { based medicine }\end{array}$} & Nothing or little & $3(5.5)$ & $8(10.5)$ & $11(8.4)$ & \multirow{3}{*}{-0.286} \\
\hline & average & $11(20.0)$ & $21(27.6)$ & $32(24.4)$ & \\
\hline & $\begin{array}{l}\text { Much and too } \\
\text { much }\end{array}$ & $41(74.5)$ & $47(61.8)$ & 88 (67.2) & \\
\hline \multirow{3}{*}{$\begin{array}{l}\text { Considering themselves socially } \\
\text { responsible }\end{array}$} & Nothing or little & $1(1.8)$ & $2(2.7)$ & $3(2.3)$ & \multirow{3}{*}{-0.762} \\
\hline & average & $12(21.8)$ & $20(26.7)$ & $32(24.6)$ & \\
\hline & $\begin{array}{l}\text { Much and too } \\
\text { much }\end{array}$ & $42(76.4)$ & $53(70.7)$ & $95(73.1)$ & \\
\hline \multirow{3}{*}{$\begin{array}{l}\text { Considering themselves able to } \\
\text { handle conflict of interests }\end{array}$} & Nothing or little & $2(3.6)$ & $3(3.9)$ & $5(3.8)$ & \multirow{3}{*}{-0.178} \\
\hline & average & $14(25.5)$ & $31(40.8)$ & $45(34.4)$ & \\
\hline & $\begin{array}{l}\text { Much and too } \\
\text { much }\end{array}$ & $39(70.9)$ & $42(55.3)$ & $81(61.8)$ & \\
\hline \multirow{3}{*}{$\begin{array}{l}\text { Interprofessional collaboration and } \\
\text { team-work }\end{array}$} & Nothing or little & $3(5.5)$ & $9(11.8)$ & $12(9.2)$ & \multirow{3}{*}{-0.032} \\
\hline & average & $12(21.8)$ & $29(38.2)$ & $41(31.3)$ & \\
\hline & $\begin{array}{l}\text { Much and too } \\
\text { much }\end{array}$ & $40(72.7)$ & $38(50.0)$ & $78(59.5)$ & \\
\hline \multirow{2}{*}{$\begin{array}{l}\text { Considering the patient as a person } \\
\text { and not calling him with a disorder }\end{array}$} & Nothing or little & $3(5.5)$ & $12(15.8)$ & $15(11.5)$ & \multirow{2}{*}{0.156} \\
\hline & average & $16(29.1)$ & $23(30.3)$ & $39(29.8)$ & \\
\hline
\end{tabular}




\begin{tabular}{|c|c|c|c|c|c|}
\hline name & $\begin{array}{l}\text { Much and too } \\
\text { much }\end{array}$ & $36(65.5)$ & $41(53.9)$ & $77(58.8)$ & \\
\hline \multirow{3}{*}{$\begin{array}{l}\text { How much did they care about } \\
\text { Nutrition and obesity? }\end{array}$} & Nothing or little & $7(12.7)$ & $7(9.2)$ & $14(10.7)$ & \multirow{3}{*}{0.553} \\
\hline & average & $13(23.6)$ & $24(31.6)$ & $37(28.2)$ & \\
\hline & $\begin{array}{l}\text { Much and too } \\
\text { much }\end{array}$ & $35(63.6)$ & $45(59.2)$ & $80(61.1)$ & \\
\hline \multirow{3}{*}{$\begin{array}{l}\text { How much did they care about } \\
\text { getting education? }\end{array}$} & Nothing or little & $14(25.5)$ & $7(9.2)$ & $21(16.0)$ & \multirow{3}{*}{$\underset{*}{0.030}$} \\
\hline & average & $22(40.0)$ & $31(40.8)$ & $53(40.5)$ & \\
\hline & $\begin{array}{l}\text { Much and too } \\
\text { much }\end{array}$ & $19(34.5)$ & $38(50.0)$ & $57(43.5)$ & \\
\hline \multirow{3}{*}{$\begin{array}{l}\text { How much did they care about } \\
\text { immunization and vaccination? }\end{array}$} & Nothing or little & $3(5.5)$ & $7(9.3)$ & $10(7.7)$ & \multirow{3}{*}{0.503} \\
\hline & average & $5(9.1)$ & $10(13.3)$ & $15(11.5)$ & \\
\hline & $\begin{array}{l}\text { Much and too } \\
\text { much }\end{array}$ & $47(85.5)$ & $58(77.3)$ & $\begin{array}{c}105 \\
(80.8) \\
\end{array}$ & \\
\hline \multirow{3}{*}{$\begin{array}{l}\text { How much did they care about } \\
\text { smoking cessation? }\end{array}$} & Nothing or little & $6(10.9)$ & $10(13.2)$ & $16(12.2)$ & \multirow{3}{*}{0.916} \\
\hline & average & $11(20.0)$ & $14(18.4)$ & $25(19.1)$ & \\
\hline & $\begin{array}{l}\text { Much and too } \\
\text { much }\end{array}$ & $38(69.1)$ & $52(68.4)$ & $90(68.7)$ & \\
\hline \multirow{3}{*}{$\begin{array}{l}\text { How much did they care about drug } \\
\text { abuse especially among youngsters? }\end{array}$} & Nothing or little & $5(9.1)$ & $7(9.2)$ & $12(9.2)$ & \multirow{3}{*}{0.914} \\
\hline & average & $11(20.0)$ & $13(17.1)$ & $24(18.3)$ & \\
\hline & $\begin{array}{l}\text { Much and too } \\
\text { much }\end{array}$ & $39(70.9)$ & $56(73.7)$ & $95(72.5)$ & \\
\hline \multirow{3}{*}{$\begin{array}{l}\text { How much did they care about } \\
\text { fastening seat belts? }\end{array}$} & Nothing or little & $17(30.9)$ & $16(21.1)$ & $33(25.2)$ & \multirow{3}{*}{0.207} \\
\hline & average & $22(40.0)$ & $27(35.5)$ & $49(37.4)$ & \\
\hline & $\begin{array}{l}\text { Much and too } \\
\text { much }\end{array}$ & $16(29.1)$ & $33(43.4)$ & $49(37.4)$ & \\
\hline \multirow{3}{*}{$\begin{array}{l}\text { How much did they care about air } \\
\text { pollution? }\end{array}$} & Nothing or little & $18(32.7)$ & $18(23.7)$ & $36(27.5)$ & \multirow{3}{*}{0.519} \\
\hline & average & $17(30.9)$ & $27(35.5)$ & $44(33.6)$ & \\
\hline & $\begin{array}{l}\text { Much and too } \\
\text { much }\end{array}$ & $20(36.4)$ & $31(40.8)$ & $51(38.9)$ & \\
\hline \multirow{3}{*}{$\begin{array}{l}\text { How much did they care about } \\
\text { unemployment? }\end{array}$} & Nothing or little & $19(34.5)$ & $15(19.7)$ & $34(26.0)$ & \multirow{3}{*}{0.161} \\
\hline & average & $15(27.3)$ & $26(34.2)$ & $41(31.3)$ & \\
\hline & $\begin{array}{l}\text { Much and too } \\
\text { much }\end{array}$ & $21(38.2)$ & $35(46.1)$ & $56(42.7)$ & \\
\hline
\end{tabular}

\section{Discussion}

In the present study, the attitudes of undergraduate medical students of QUMS toward medical professionalism and professional behavior were examined. The result of this study may be used in the planning of curricular content and methods that are more acceptable to trainees. Also, these data may assist in creating didactic strategies that improve the quality of practice of early career physicians.

Although, most trainees believed that professionalism and ethics should be taught and learned, surprisingly, interns less strongly 
endorse the benefits of professionalism and ethics preparation than clerks. Half of trainees considered ethics as a formal course in the medical school curriculum and most of them $(68.5 \%)$ believed that suitable time of ethical and professional teaching is throughout the course. In our study, Although the need for appropriate role models during medical training is imperative (8) and despite the importance of role models to success of professionalism education, only one fifth of students considered role modeling as the only way to learn professionalism. There are different possible explanations for the difference between our students' opinion and what we expect for role modeling in learning professionalism. Unfortunately, many factors lead to less time to supervise and teach learners, limited opportunity for study and research, and decreasing time for community involvement (9). Also, when the teaching of professionalism is limited to one or more formal didactic sessions outlining the cognitive base, the impact will be minimal. For many years, the acquisition of professionalism occurred largely through an informal process and role modeling remained critically important (10). Since medical practice issues have become more complicated, such an informal process no longer considers sufficient.

Different learning approaches (e.g., clinicallyoriented, non-traditional formats) are valued by our participants. Similarly, diverse learning approaches (e.g., clinically-oriented, non-traditional formats) are valued by participants of Medical College of Wisconsin (11). Also, in another study, clinicallyoriented teaching of professionalism was strongly preferred over structured teaching. In University of North Dakota, School of Medicine and Health Sciences, a pre-clinical patient-centered learning (PCL) process generates innovative opportunities for professionalism education at the student level. In their PCL format, classes are divided into groups of six to eight students who meet three times a week to analyze a clinical case. Each small group also includes a faculty member who facilitates the group process, rather than instructing students about case content (12).

Currently, physicians do not work alone (12) and health care work patterns are shifting to be more team-based (13). Effective teamwork has been shown to improve the quality of patient care $(14,15)$, yet until recently has not been included in our curricula. Currently in our country, health care professionals are poorly prepared by their education for their roles in a team. In our study, majority of 
medical students believed that interprofessional collaboration and team-work are important but they poorly prepared for the inevitable teamwork in which they need to be involved. The difficulties encountered in working with professionals from different disciplines arise from a lack of knowledge of different roles, lack of skills in teamwork and variable levels of respect, all of them are amenable to change through education (16).

There is no agreed-upon definition of domains of professional medical practice. Patient care, medical knowledge, practicebased learning and improvement, interpersonal and communication skills, professionalism, and systems-based practice (including health economics and teamwork) were defined as areas of competence by The Accreditation Council for Graduate Medical Education (17). In our study more than $85 \%$ of the students showed moderate to very high levels of attention to some parameters and predictors of professional behaviors such as life-long learning and updating their knowledge, getting the most reliable information and applying it in their daily practice, knowing the principles of evidencebased medicine, being socially responsible and committed to social justice, being pleased to be supervised, having updated technical skills and adaptability and adjustability, being able to manage conflict of interests, constructive interaction with other members of the healthcare team, good interaction and knowing the principles of teamwork, and considering the patient as a person (i.e. avoiding to call them with the medical disorder names instead of their names).

About $43 \%$ of the participants had paid little attention to report their own medical errors or unqualified colleagues to the related organizations that is a considerable proportion and makes concerns about the future of their professional behavior in case they don't fix the problem. In the study of Lauris et al, most respondents agreed that reporting errors improves the quality of care for future patients and would likely report a hypothetical error resulting in minor or major harm to a patient. However, only $17.8 \%$ of respondents had reported an actual minor error, and only $3.8 \%$ had reported an actual major error. One reason for underreporting errors may be a lack of knowledge (18).

Some health-related factors such as nutrition and obesity, education, cessation of smoking and drugs, fastening seat belts and air pollution were very important based on the viewpoints of medical students.

Some aspects of professional behavior were 
weak among the participants. Only a few number of the medical students were in contact with their patients for diagnostic and therapeutic purposes through E-mails, used online medical education methods and computerized decision making software, participated in social services, read more than one paper in a week, used online journals, could appraise the new clinical science, and applied the principles of medical professionalism while practicing medicine. Variations in students' scores based on their level of training show a decrease in professional practice. This finding prompts us to ask whether a hidden curriculum exists in the constructs of medical education that inhibits rather than facilitates the development of professional practice.

By having such data a better professionalism curriculum can be planned in which the strong points of the future specialists can become stronger and the weak points can become strong while their beliefs and insight perfection are also being respected. Limitations of the study include the use of trainee at a single institution.

\section{Conclusion}

The undergraduate medical students had a positive attitude toward the principles of professionalism but they did not apply them widely in their behavior and practice. For making them more professional and responsible, professionalism curriculum should be planned in a comprehensive way by using appropriate contents and formats including longitudinal courses and integrated teaching of professionalism with clerkship and internship rotations.

\section{Acknowledgment}

The authors would like to express their gratitude to Education Development Office of the Faculty of Medicine of Qazvin University of Medical Sciences which supported us in conducting this study. This paper is based on the results of a student's dissertation.

\section{References}

1- Brainard AH, Brislen HC. Viewpoint: learning professionalism: a view from the trenches. Academic Medicine. 2007;82(11):1010-4.

2- Mclean M, Jha V, Sandars J. Professionalism under fire: Conflict, war and epidemics. Medical teacher. 2015;37(9):8316.

3- rnold L, Stern DT. What is medical professionalism. Measuring medical professionalism. 2006:15-37. 
4- Cruess RL, Cruess SR. Expectations and obligations: professionalism and medicine's social contract with society. Perspectives in Biology and Medicine. 2008;51(4):579-98.

5- Patenaude J, Niyonsenga T, Fafard D. Changes in students' moral development during medical school: a cohort study. Canadian Medical Association Journal. 2003;168(7):840-4.

6- Stockley AJ, Forbes K. Medical professionalism in the formal curriculum: 5 th year medical students' experiences. BMC medical education. 2014;14(1):1.

7- Nemati S. Survey of the Attitudes of Residents of Guilan University of Medical Sciences toward Medical Professionalism, and Their Professional Behaviours. Future of Medical Education Journal. 2013;3(2):18-23. 8- Ratanawongsa N, Bolen S, Howell EE, Kern DE, Sisson SD, Larriviere D. Residents' perceptions of professionalism in training and practice: barriers, promoters, and duty hour requirements. Journal of general internal medicine. 2006;21(7):758-63.

9- Nierman DM. Professionalism and the teaching of clinical medicine: perspectives of teachers and students. The Mount Sinai Journal of Medicine, New York. 2002;69(6):410-1.

10- Swick HM, Szenas P, Danoff D,
Whitcomb ME. Teaching professionalism in undergraduate medical education. Jama. 1999;282(9):830-2.

11- Roberts LW, Hammond KAG, Geppert CM, Warner TD. The positive role of professionalism and ethics training in medical education: a comparison of medical student and resident perspectives. Academic Psychiatry. 2004;28(3):170-82.

12- Christianson CE, McBride RB, Vari RC, Olson L, Wilson HD. From traditional to patient-centered learning: curriculum change as an intervention for changing institutional culture and promoting professionalism in undergraduate medical education. Academic Medicine. 2007;82(11):1079-88.

13- Cribb A. The diffusion of the health agenda and the fundamental need for partnership in medical education. Medical education. 2000;34(11):916-20.

14- Borrill C, West M, Shapiro D, Rees A. Team working and effectiveness in health care. British Journal of Healthcare Management. 2000;6(8):364-71.

15- Baker D, Gustafson S, Beaubien J, Salas E, Barach P. Medical teamwork and patient safety: the evidence-based relation: Agency for Healthcare Research and Quality publication, (05-0053); 2005. Available from: https:/www.researchgate.net/profile/ 
Paul_Barach/publication/233969549_Medical

_Teamwork_and_Patient_Safety_The_Eviden ce-Based_Relation/links/0fcfd50d8e8435cc4 9000000.pdf

16- McNair RP. The case for educating health care students in professionalism as the core content of interprofessional education. Medical education. 2005;39(5):456-64.

17- Swing SR. The ACGME outcome project: retrospective and prospective. Medical teacher. 2007;29(7):648-54. 18- Kaldjian LC, Jones EW, Wu BJ, FormanHoffman VL, Levi BH, Rosenthal GE. Reporting medical errors to improve patient safety: a survey of physicians in teaching hospitals. Archives of internal medicine. 2008;168(1):40-6. 